\title{
On the simultaneous openness hypothesis: FDI, trade and TFP dynamics in Sub-Saharan Africa
}

Simplice A. Asongu ${ }^{1 *}$, Joseph Nnanna ${ }^{2}$ and Paul N. Acha-Anyi ${ }^{3}$

*Correspondence:
asongusimplice@yahoo.com;
asongus@afridev.org
${ }^{1}$ African Governance
and Development Institute,
P.O Box 8413, Yaoundé,
Cameroon
Full list of author information
is available at the end of the
article

*Correspondence: asongusimplice@yahoo.com; 1 African Governance and Development Institute, 8413, Yaoundé,

Full list of author informatio article

\begin{abstract}
This study assesses the simultaneous openness hypothesis that trade modulates foreign direct investment (FDI) to induce positive net effects on total factor productivity (TFP) dynamics. Twenty-five countries in Sub-Saharan Africa and data for the period 1980 to 2014 are used. The empirical evidence is based on the Generalized Method of Moments. First, trade imports modulate FDI to overwhelmingly induce positive net effects on TFP, real TFP growth, welfare TFP and real welfare TFP. Second, with exceptions on TFP and welfare TFP where net effects are both positive and negative, trade exports modulate FDI to overwhelmingly induce positive net effects on real TFP growth and welfare real TFP. In summary, the tested hypothesis is valid for the most part. Policy implications are discussed.
\end{abstract}

Keywords: Productivity, Foreign investment, Sub-Saharan Africa

JEL Classification: E23, F21, F30, L96, O55

\section{Introduction}

The objective of this research is to assess the relevance of trade dynamics in moderating the effect of foreign investment on productivity dynamics in Sub-Saharan Africa. The study is tailored within the context of a simultaneous hypothesis such that foreign direct investment (FDI) is complemented with dynamics of trade to influence productivity. Accordingly, it is an improved framing of the Rajan and Zingales (2003) position that concurrent opening of trade and capital accounts will lead to greater output in a domestic economy. Moreover, the problem statement underlying this exposition is motivated within the broader context of: (i) debates in the contemporary literature on the relevance of total factor productivity (TFP) and (ii) gaps in the attendant literature. These motivational elements are expanded in the following passages.

First, no consensus is apparent in the literature on the relevance of productivity in development outcomes in Africa. In essence, while a strand of studies posits that aggregate productivity is essential in boosting economic development, authors are still divided on the mechanisms through which productivity can be boosted (Elu and Price 2010; Baliamoune 2009; Baliamoune-Lutz 2011; Asongu 2013; Asongu 2014a; Ssozi and 
Asongu 2016a; Tchamyou 2017; Cheruiyot 2017). Among conflicting perspectives, a debate that is worth mentioning is one that centres on factor accumulation and TFP. One group, building on examples and success stories of East Asia posit that the relevance for factor accumulation is higher compared to TFP in the prosperity of nations (Young 1995; Asongu 2017). Conversely, another group of authors is of the perspective that, cross-country differences in economic outcomes are significantly traceable to disparities or variations in cross-country levels of TFP (Abramovitz 1986; Romer 1986, 1993; Klenow and Rodriguez-Clare 1997; Temple 1999; Nelson and Howard Pack 1999; Easterly and Levine 2001; Durlauf et al. 2005). As maintained by Devarajan et al. (2003), the African poverty tragedy is accounted for more, by low TFP than it is by investment levels. The authors caution on the importance of prioritizing TFP in place of investments in order to lift the continent out of poverty. This research contributes to the growing debate by assessing how trade openness can modulate FDI to influence TFP dynamics in Sub-Saharan Africa (SSA). This positioning is also buttressed by a corresponding gap in the scholarly literature.

Second, to the best of our knowledge, scholarship on the main variables of interest in the study can be engaged in two main strands, pertaining to TFP- and FDI-centric studies. The first on TFP-oriented scholarship has fundamentally focused on, inter alia: gender disparities and labour supply in SSA (Elu and Price 2017); the rate of child labour and schooling features (Ahouakan and Diene 2017); linkages between manufacturing and exports (Cisse 2017); examinations of nexuses between manufacturing firms and TFP within the framework of variations of productivity prosperity across sectors in the manufacturing industry (Kreuser and Newman 2018) and the importance of information technology in TFP convergence (Maryam and Jehan 2018). The second pertaining to FDI-centric research includes: regional income convergence and FDI (Dunne and Nicholas Masiyandima 2017); how portfolios in Africa's economic sectors are influenced by more globalized sectors (Boamah 2017); nexuses between concepts underlying equity, bonds, institutional debts and economic prosperity (Fanta and Makina 2017); modelling output gaps in view of future economic prosperity (Fedderke and Mengisteab 2017) and how value chains are relevant in boosting the influence on economic growth and TFP (Meniago and Asongu 2019).

The study that is closest to the present exposition is Sakyi and Egyir (2017) which has focused on the simultaneous openness hypothesis with particular emphasis on interactions between trade openness and FDI for economic growth in the continent of Africa. The authors assess the hypothesis that positive ramifications in terms of economic growth can be derived from interactions between exports and FDI. The geographical and temporal scopes are, respectively, 45 African countries and the period spanning from 1990 to 2014. Using the Generalized Method of Moments (i.e. GMM), the findings reached by the authors support the tested hypothesis.

This study steers clear of Sakyi and Egyir (2017) from a number of fronts. (i) Within a methodological perspective, this research adopts the GMM option that is based on forward orthogonal deviations because compared to the system GMM option used by the underlying study, the approach adopted in this research has been documented to produce more reliable estimated coefficients because, it among others, diminishes instrument proliferation which has been established to bias estimated coefficients in the 
attendant contemporary GMM-centric literature (Meniago and Asongu, 2018; Tchamyou et al. 2019; Tchamyou 2020). For instance, the information criteria disclosed by the underlying study does not provide insights into this concern of instrument proliferation because the number of instruments and corresponding number countries are not disclosed for each specification, to enable an examination of whether specifications are biased by the presence of instrument proliferation. (ii) Instead of focusing on economic growth, this research is concerned with TFP dynamics. (iii) Contrary to the assessment of the tested simultaneous openness hypothesis on the premise of marginal, interactive or conditional effects, this research considers net effects (constituting both the conditional and unconditional effects) as an information criterion in the assessment of the simultaneous openness hypothesis. In essence, as emphasized by Brambor et al. (2006) on the setbacks of interactive specifications, both the conditional and unconditional impacts are relevant for the assessment of how the modulating variables interact with the main independent variable of interest to influence the outcome variable. This conception and understanding of the relevance of net effects in interactive regressions is consistent with the attendant contemporary literature on interactive specifications (Tchamyou and Asongu 2017; Agoba et al. 2020; Tchamyou 2019).

(iv) This research also takes on board some prevailing concerns pertaining to Sustainable Development Goals (SDGs) which are quite imperative in the post-2015 development agenda. Accordingly, departing from the strand of TFP literature which has fundamentally been based on one indicator of TFP, this research is consistent with concerns of inclusive productivity and output by adopting inclusive TFP measurements to complement the mainstream TFP indicator, namely: real TFP, welfare TFP and real welfare TFP. Hence, it also departs from Asongu et al. (2020) by focusing on TFP instead of economic growth dynamics.

The remainder of the study is structured as follows. This introduction is followed by a section on theoretical underpinnings surrounding, on the one hand, the role of openness in economic development and on the other, the importance of FDI in TFP. A section covering the data and methodology comes after these theoretical insights, followed by an empirical results section in which the findings are presented and discussed. The study concludes in the last section with implications and future research directions.

\section{Theoretical underpinnings}

\subsection{Globalization and economic development}

The nexus between globalization and economic development is clarified by two main theoretical schools of thought, namely: the hegemonic and the neoliberal paradigms of economic thought (Tsai 2006; Asongu and Nwachukwu 2017a). With regard to the first paradigm on hegemony, globalization is a phenomenon that is hiding an agenda meant to establish a world order that would be driven by developed countries, multinational corporations, multilateral organizations and international financial institutions. The school posits that the fundamental premises of the hidden agenda are characterized by capital accumulation, enhanced cross-country market interactions and transactions as well as the exploitation of cheap sources of human resources (Petras and Veltmeyer 2001). Moreover, there is increasing evidence that policies favouring openness in developing countries have fundamentally benefited richer elements of society to the 
detriment of their poorer counterparts. Building on this evidence, Petras and Veltmeyer (2001) envisage "a world-wide crisis of living standards for labor" owing to positions that "technological change and economic reconversion endemic to capitalist development has generated an enormous growing pool of surplus labor, an industrial reserve army with incomes at or below the level of subsistence" (p. 24).

The hegemonic school also maintains that the paradigm of globalization is characterized by production modes that substantially undervalue channels by which the fruits of economic prosperity are equitably distributed among the population. For instance, as argued by Asongu and Nwachukwu (2017a), such an unequal mechanism for the distribution of fruits of productivity run counter to the tenets of Keynesian Social Democracy. Other positions supporting the narrative include: the role of globalization in disregarding inclusive development and promoting self-interest (Smart 2003; Tsai 2006) and the benefits of globalization weighing in favour of wealthier elements of society (Scholte 2000; Sirgy et al. 2004).

From the prism of the neoliberal paradigm, globalization reflects a mechanism of "creative destruction" through which competition improves standards of living by means of enhanced cross-border trade, improvements in technology, efficient allocation of human resources and capital flows from developed countries experiencing lower marginal productivity of capital to developing countries characterized by higher marginal productivity of capital (Asongu 2014b). According to the school, while globalization has obvious shortcomings such as job losses and drops in workers' wages, there is a mechanism of compensation because the unskilled are provided with opportunities of getting the relevant competitive and scarce skills needed in an ever-growing competitive process in the global labour market. This is consistent with Grennes (2003) who maintains that the rewards of openness in trade and capital are apparent in the labour market.

\subsection{FDI and productivity}

In accordance with the literature on external flows (Toone 2013; Gammoudi et al. 2016), there are three fundamental theoretical insights supporting the nexuses between FDI and productivity, namely: the dependency theory, the classical theory and middle path theory.

First, the dependency theory is fundamentally motivated by the features of Marxism which understand globalization as the measure by which market capitalism is propagated across the globe. Such propagation entails the use of more advanced technologies in exchange for relatively cheap sources of labour. Consistent with proponents of this theory, economic development in host economies is negatively connected with foreign investment for three main justifications. (i) The benefits of foreign investment are not distributed equally between multinational companies and governments of domestic economies because for the most part, the benefits are skewed to the interest of multinational companies. In accordance with the perspective, local assets that are worthwhile in providing funds for economic development in host economies are absorbed by foreign investment features that make use of opportunities of economic development in developing countries as well as the repatriation of profits to tax havens and technically advanced countries (Jensen 2008). 
(ii) International corporations represent a source of domestic market distortions by among others: changing customers' tastes, undermining local culture, damaging wealth distribution and adopting capital-intensive technologies that may not be appropriate for domestic investment opportunities (Taylor and Thrift 2013). (iii) Some future alliance among the elite and foreign investors can be tailored to serve the exclusive interests of parties in the alliance with limited focus on more lofty wellbeing agenda of society and equitable distribution of fruits from economic output. Jensen (2008) is consistent with this narrative in view of the fact that, since citizens are fundamentally excluded from the underlying alliances, significant political distortions end up characterizing the system.

The classical theory posits that FDI is an important source of domestic economic development because it is sustained by a plethora of channels, inter alia: capital transfers; improvements in balance of payments; utilization of ameliorated equipments and technology; employment avenues; FDI-driven export; foreign exchange earnings; integration of host economies into global markets and infrastructural development (Toone 2013; Gammoudi et al. 2016). These theoretical insights are considerably documented in the literature pertaining to "spillovers": a phenomenon that is realized "when the entry or presence of multinational corporation increases productivity of domestic firms in the host country and the multinationals do not fully internalize the value of these benefits" (Javorcik 2004, p. 607). Spillover origins which are many embody: usage of technology; working methods and insights into the management of skills that are likely to enhance productivity and output.

The "middle path" theory is a paradigm that reconciles the previous two theoretical insights fundamentally because while it cautions against the negative ramifications of foreign investment advanced by the dependency theory, it also acknowledges the benefits advanced by the classical theory in the previous paragraph (Gammoudi et al. 2016). This theory recommends openness policies to align with measures of government regulation in order to address the negative issues associated with full or complete openness of trade and capital accounts. These regulation policies can also be tailored such that FDI is channelled to targeted sectors of the economy as well as geographical locations that are characterized with some disadvantages that domestic governments are focused on addressing.

Building on the theoretical underpinnings discussed above, the study argues that trade openness can modulate FDI to induce positive effects on TFP productivity dynamics. The theoretical importance of trade as a policy instrument in moderating FDI for enhanced productivity is consistent with the insights disclosed by Hussien et al. (2012). According to the authors, international trade is acknowledged as a crucial determinant of TFP because, inter alia, trade: eases the processes of adopting new technology (Holmes and Schmitz 1995) and enhances the reallocation of resources to more efficient corporations from their less efficient counterparts in order to enhance overall productivity and output (Melitz 2003). The corresponding testable research hypothesis is the following.

Hypothesis 1 trade openness complements FDI for overall positive effects on TFP dynamics. 
Whether this stated hypothesis withstands empirical scrutiny is the focus of the following sections.

\section{Data and methodology}

\subsection{Data}

The study uses data from 25 countries in SSA. ${ }^{1}$ The period of study is from 1980 to 2014. The restriction to the number of countries and corresponding periodicity are motivated by constraints in TFP data at the time of the study. In order to align the data structure with the empirical strategy to be adopted by the research, the data are restructured in terms of non-overlapping intervals in order to ensure that the number of cross sections is superior to the number of annual observations in every cross section: such is a condition for the employment of the GMM empirical strategy. The study derives five 7-year and seven 5-year non-overlapping averages and after a preliminary investigation, it is apparent that the latter set of data averages leads to instrument proliferation and by extension unrobust estimated models, even when the option of collapsing instruments is taken on board. Hence, the five 7-year data averages that are retained for the study are: 1980-1986; 1987-1993; 1994-2000; 2001-2007; 2008-2014. ${ }^{2}$

The main independent variable of interest which is foreign direct investment (FDI) comes from the United Nations Conference on Trade and Development (UNCTAD) FDI database. It is measured as FDI inflows as a percentage of Gross Domestic Product (GDP). The Penn World Table database is the source of the TFP dynamics, namely: TFP, real TFP, welfare TFP and real welfare TFP. In accordance with the motivational elements of this research articulated in the introduction, the main TFP is complemented with other dynamics in order to provide room for findings that are relevant to SDGs (Asongu 2020). Therefore, the adopted TFP variables are consistent with both productivity and the welfare implications of such output.

The trade moderating variables which have been theoretically justified towards the end of Sect. 2.2, building on Hussien et al. (2012), are exports and imports of commodities from World Development Indicators (WDI) of the World Bank. The adopted elements in the conditioning information set employed to control for variable omission bias are from the WDI and the Financial Development and Structure Database (FDSD) of the World Bank. While private domestic credit is from the FDSD, remittances, government expenditure and inclusive education are from the WDI of the World Bank. The selection of these conditioning indicators is informed by the attendant productivity and output scholarship (Becker et al. 1999; Barro 2003; Heady and Hodge 2009; Sahoo et al. 2010; Ssozi and Asongu 2016a; Tchamyou 2017). With the exception of remittances that are anticipated to negatively influence the outcome variables, the remaining three indicators are expected to positively affect the engaged TFP dynamics. These expected signs are expanded in the following passages.

\footnotetext{
${ }^{1}$ The countries, selected on data availability are: Benin; Botswana; Burkina Faso; Burundi; Cameroon; Central African Republic; Cote d'Ivoire; Gabon; Kenya; Lesotho; Mauritania; Mauritius; Mozambique; Namibia; Niger; Nigeria; Rwanda; Senegal; Sierra Leone; South Africa; Sudan; Swaziland; Tanzania; Togo and Zimbabwe.

2 The rationale of using data averages is to avoid instrument proliferation during post-estimation diagnostics tests. For instance, it is apparent in the findings that the number of instruments is consistently lower than the corresponding number of cross sections in each specification.
} 
First, while remittances have been documented to positively influence output in Africa (Ssozi and Asongu 2016b; Asongu et al. 2019), the effect is also contingent on the proportion of remittances allocated for consumption purposes. Hence, in scenarios where remittances are used more for consumption than for production, the expected positive effect should be taken with caution. Hence, a priori, the sign of the indicator cannot be determined with absolute certainty. However, it is expected to significantly affect the outcome variable. Second, the caution on the expected sign from remittances can also be extended to financial access and government expenditure which have also been documented to positively affect output and productivity (Asongu 2015; Nyasha and Odhiambo 2015a, b). On the one hand, if government expenditure is tailored more for expenses that are designed to boost economic output, the expected sign should be positive. However, if such expenditure is clouded in corrupt practices and largely tailored towards unproductive investments, a negative sign can be expected. On the other, the allocation of credit to productive investments from intuition is likely to increase productivity while the corresponding productivity is anticipated to decrease if such credit is allocated for productive investments. Third, the importance of education in driving socio-economic progress has been substantially documented in the economic development literature (Petrakis and Stamatakis 2002; Asiedu 2014; Tchamyou 2020). The definitions and sources of variables are provided in Appendix 1, the summary statistics is disclosed in Appendix 2 while the correlation matrix is provided in Appendix 3.

\subsection{Methodology}

\subsubsection{Specification}

Some insights into the choice of the GMM empirical strategy have already been provided in the data section, notably: the need to restructure the data in order to fulfil an elementary requirement for the adoption of the estimation approach. Accordingly, after restructuring the dataset in terms of five 7-year non-overlapping intervals, the $N>T$ condition that is imperative for the choice of the empirical strategy is met. ${ }^{3}$ Other justifications for the choice of the technique include: (i) persistence in the TFP dynamics in the light of the fact that their first difference and level series are correlated to a height that is higher than 0.800 which is the established threshold in contemporary GMM-oriented literature as the rule of thumb for the establishment of persistence in an outcome indicator (Asongu et al. 2017; Tchamyou et al. 2018; Tchamyou 2019; Efobi et al. 2019).

(ii) Cross-country variations are acknowledged in the estimation exercise because the data structure is panel-oriented. (iii) The issue of endogeneity that is imperative for a robust empirical analysis is taken on board from two main premises, notably: simultaneity or reverse causality is addressed by the adoption of internal instruments and the time invariant omitted indicators are also employed to take into account the unobserved heterogeneity.

\footnotetext{
${ }^{3}$ The main period is 1980-2014 and using 7-year data averages produces five data points (1980-1986; 1987-1993; 1994-2000; 2001-2007; 2008-2014). Hence, 1980-1986 is an average corresponding to a data point; $1987-1993$ is also an average corresponding to a data point and so on. Therefore, the findings cannot be presented exclusively for a given data point because, it would amount to a cross-sectional study and as we all know; at least 5 data points are required for the use of GMM (Asongu and Nwachukwu 2017c). The rationale of using data averages to avoid instrument proliferation during post-estimation diagnostics tests is apparent in the presented findings in which, the number of instruments is consistently lower than the corresponding number of cross sections in each specification.
} 
The following equations in levels (1) and first difference (2) summarize the estimation procedure for the relevance of trade dynamics in modulating FDI to influence TFP:

$$
\begin{array}{r}
\operatorname{TFP}_{i, t}=\sigma_{0}+\sigma_{1} \operatorname{TFP}_{i, t-\tau}+\sigma_{2} \operatorname{FDI}_{i, t}+\sigma_{3} T_{i, t}+\sigma_{4} \operatorname{Inter}_{i, t}+\sum_{h=1}^{4} \delta_{h} W_{h, i, t-\tau}+\eta_{i}+\xi_{t}+\varepsilon_{i, t}, \\
\operatorname{TFP}_{i, t}-\operatorname{TFP}_{i, t-\tau}=\sigma_{1}\left(\operatorname{TFP}_{i, t-\tau}-\operatorname{TFP}_{i, t-2 \tau}\right)+\sigma_{2}\left(\operatorname{FDI}_{i, t}-\operatorname{FDI}_{i, t-\tau}\right)+\sigma_{3}\left(T_{i, t}-T_{i, t-\tau}\right) \\
\quad+\sigma_{4}\left(\operatorname{Inter}_{i, t}-\operatorname{Inter}_{i, t-\tau}\right)+\sum_{h=1}^{4} \delta_{h}\left(W_{h, i, t-\tau}-W_{h, i, t-2 \tau}\right)+\left(\xi_{t}-\xi_{t-\tau}\right)+\left(\varepsilon_{i, t}+\varepsilon_{i, t-\tau}\right),
\end{array}
$$

where $\mathrm{TFP}_{i, t}$ denotes total factor productivity dynamics (i.e. real TFP, TFP, real welfare TFP and welfare TFP) of country $i$ in period $t$; FDI represents foreign direct investment; $T$ is a trade dynamic (i.e. imports and exports); Inter reflects the interaction between FDI and a trade dynamic; $\sigma_{0}$ is a constant; $\tau$ is the degree of auto-regression which is acknowledged as one in this research because a one period lag or 7-year non-overlapping interval is required to capture previous information; $W$ entails the vector of control variables (government expenditure, education, remittances and private domestic credit), $\eta_{i}$ is the country-specific effect, $\xi_{t}$ is the time-specific constant and $\varepsilon_{i, t}$ the error term. Equations (1) and (2) are replicated for other TFP dynamics, notably: real TFP, welfare TFP and real welfare TFP. For the purpose of this research, the GMM empirical approach with forward orthogonal deviations is adopted. This GMM option which is an improved version of the Arellano and Bover (1995) approach by Roodman (2009) has been documented to provide estimated coefficients that are more efficient compared to less contemporary difference and system GMM approaches (Boateng et al. 2018; Tchamyou et al. 2019).

\subsubsection{Identification, simultaneity and exclusion restrictions}

For every GMM strategy, clarification on identification, simultaneity and exclusion restrictions are very fundamental for a tight specification. This research takes the specifics in turn. First, the identification framework entails the definitions of three categories of variables involved in the specification exercises, namely, the outcome variables, the predetermined or endogenous explaining variables and the strictly exogenous variables. Obviously, the outcome variables are dynamics of TFP. Building on contemporary GMM-oriented studies based on forward orthogonal deviations, the strictly exogenous variables are years while the endogenous explaining indicators are independent variables of interest (FDI and trade dynamics) and adopted control variables(Tchamyou and Asongu 2017; Meniago and Asongu 2018). It is important to clarify that this approach to identification and exclusion restriction is broadly consistent with Roodman (2009) who has argued that years are feasible strictly exogenous variables because they cannot become endogenous after a first difference. It follows from these clarifications that the exclusion restriction assumption underpinning the identification process is based on the assumption that the identified strictly exogenous variables influence the outcome variable exclusively via the identified predetermined variables. 
Second, the concerns about simultaneity corresponding to the issue of reverse causality are taken on board through instrumental variables that are forward differenced. The process entails the use of Helmert transformations to eliminate fixed impacts that are susceptible to biasing estimated coefficients owing to a correlation between the lagged outcome variable and fixed effects. This procedure to purging fixed effects is consistent with extant literature on the subject (Arellano and Bover 1995; Love and Zicchino 2006; Roodman 2009). These transformations permit orthogonal or parallel conditions between lagged and forward differenced observations.

Third, the exclusion restriction assumption clarified in the first strand of this section can be assessed with the Difference in Hansen Test (DHT) within a GMM framework based on forward orthogonal deviations. The null hypothesis of the underlying test should not be rejected because it is the position that the identified strictly exogenous variables influence the TFP dynamics exclusively via the engaged predetermined variables. This criterion for validating exclusion restrictions is not very different from traditional instrumental variable (IV) approaches that are founded on the basis that the null hypothesis of the Sargan/Hansen test should not be rejected in order for the exclusion restriction assumption to hold (Beck et al. 2003; Amavilah et al. 2017).

\section{Empirical results}

\subsection{Presentation of results}

This section provides the empirical findings in Tables 1, 2, 3, 4. While Table 1 is concerned with linkages between TFP, FDI and trade, the focus of Table 2 is on real TFP growth, FDI and trade. In Table 3, findings pertaining to linkages between welfare TFP, FDI and trade are disclosed while results on nexuses between welfare real TFP, FDI and trade are provided in Table 4. Each table is characterized by sub-sections pertaining to import- and export-oriented specifications on the left-hand and right-hand side, respectively. Moreover, five main specifications feature in each sub-section: four with one conditioning information set and one without a conditioning information set.

It is worthwhile to emphasize that limiting of elements in the conditioning information set is a common practice in so far as the objective of doing so is to avoid instrument proliferation that potentially bias estimated GMM models. Hence, even when the option of collapsing instruments is taken on board, it is apparent that only one variable from the conditioning information set can be involved in each regression. For instance, examples of GMM-centric studies that have not engaged control variables with the objective of avoiding instrument proliferation are: Osabuohien and Efobi (2013) and Asongu and Nwachukwu (2017d).

For every specification, the overall validity of models is informed by four criteria of information. ${ }^{4}$ Based on these criteria, the estimated models are overwhelmingly valid with

\footnotetext{
4 "First, the null hypothesis of the second-order Arellano and Bond autocorrelation test (AR (2)) in difference for the absence of autocorrelation in the residuals should not be rejected. Second the Sargan and Hansen over-identification restrictions (OIR) tests should not be significant because their null hypotheses are the positions that instruments are valid or not correlated with the error terms. In essence, while the Sargan OIR test is not robust but not weakened by instruments, the Hansen OIR is robust but weakened by instruments. In order to restrict identification or limit the proliferation of instruments, we have ensured that instruments are lower than the number of cross sections in most specifications. Third, the Difference in Hansen Test (DHT) for exogeneity of instruments is also employed to assess the validity of results from the Hansen OIR test. Fourth, a Fisher test for the joint validity of estimated coefficients is also provided" (Asongu and De Moor 2017, p. 200).
} 


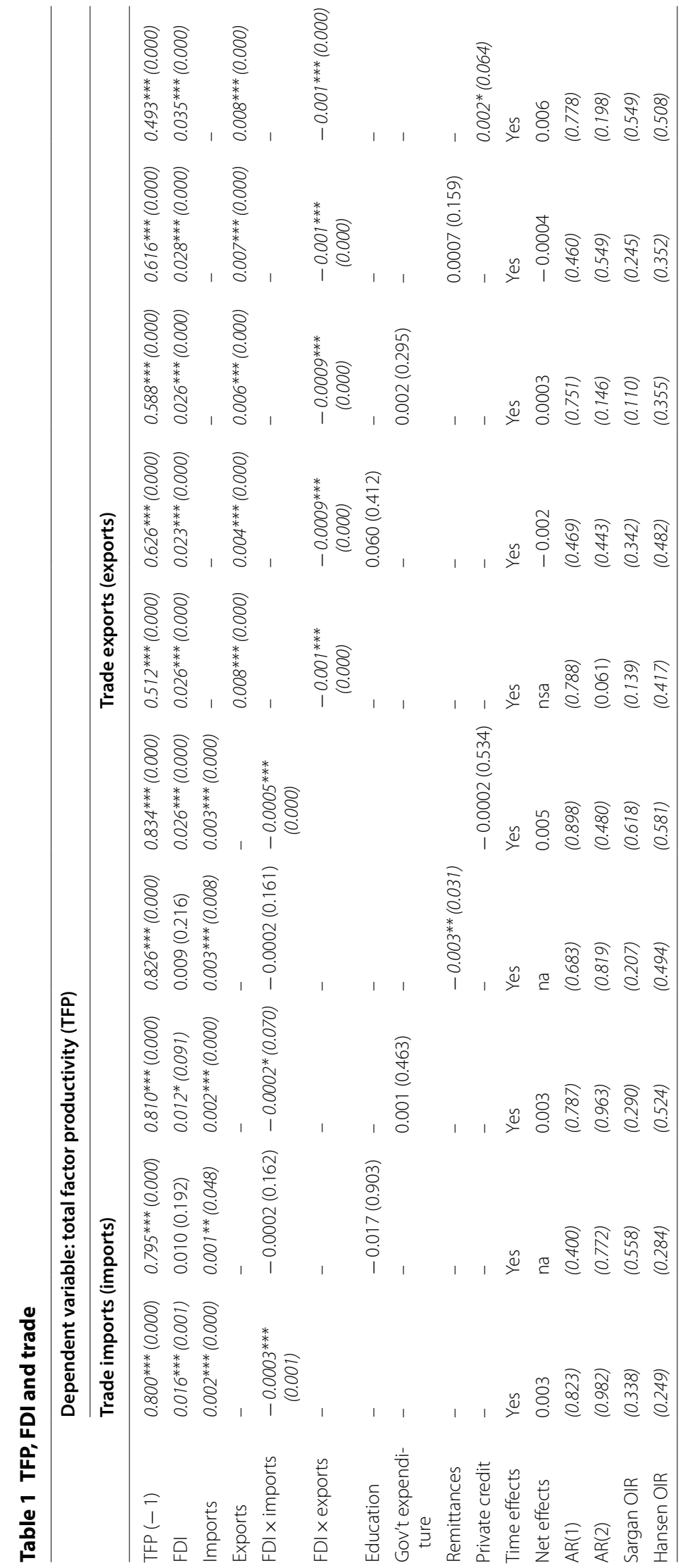




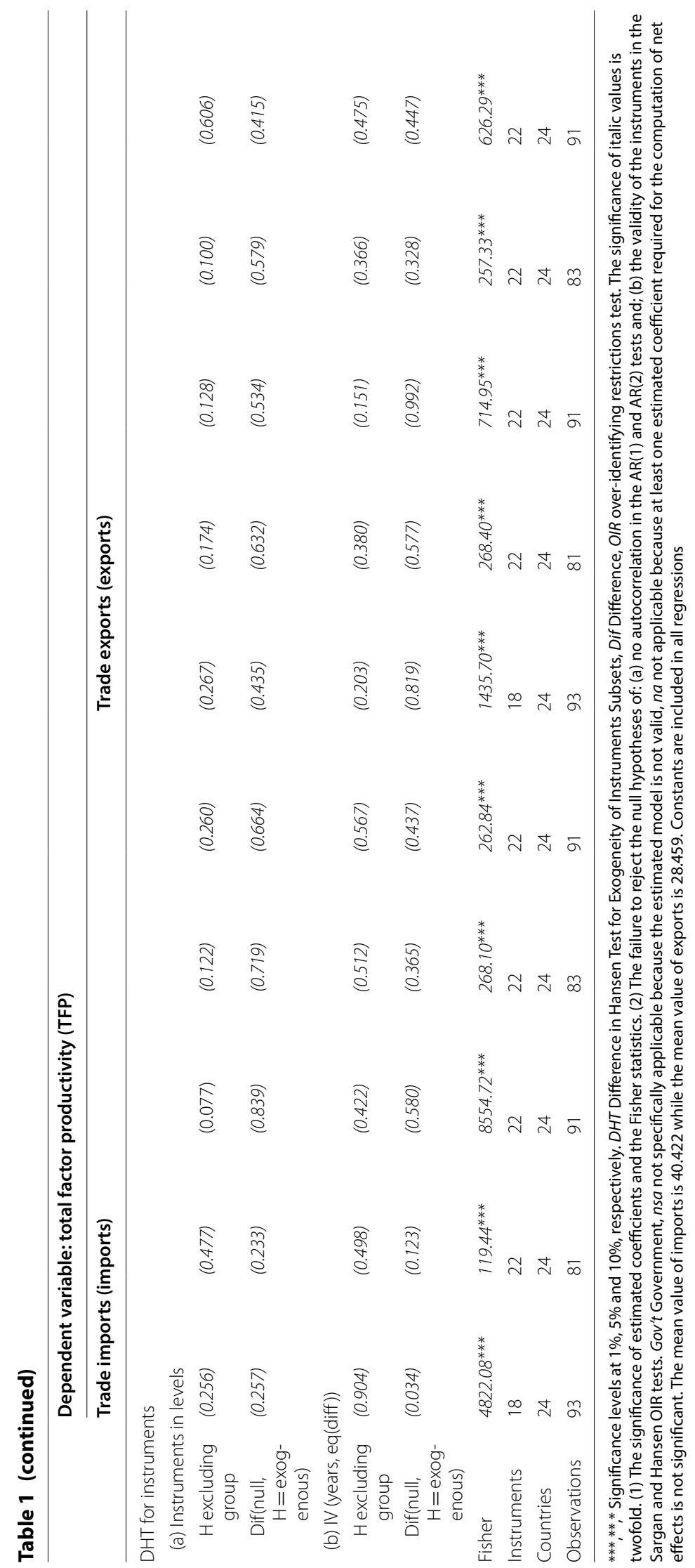




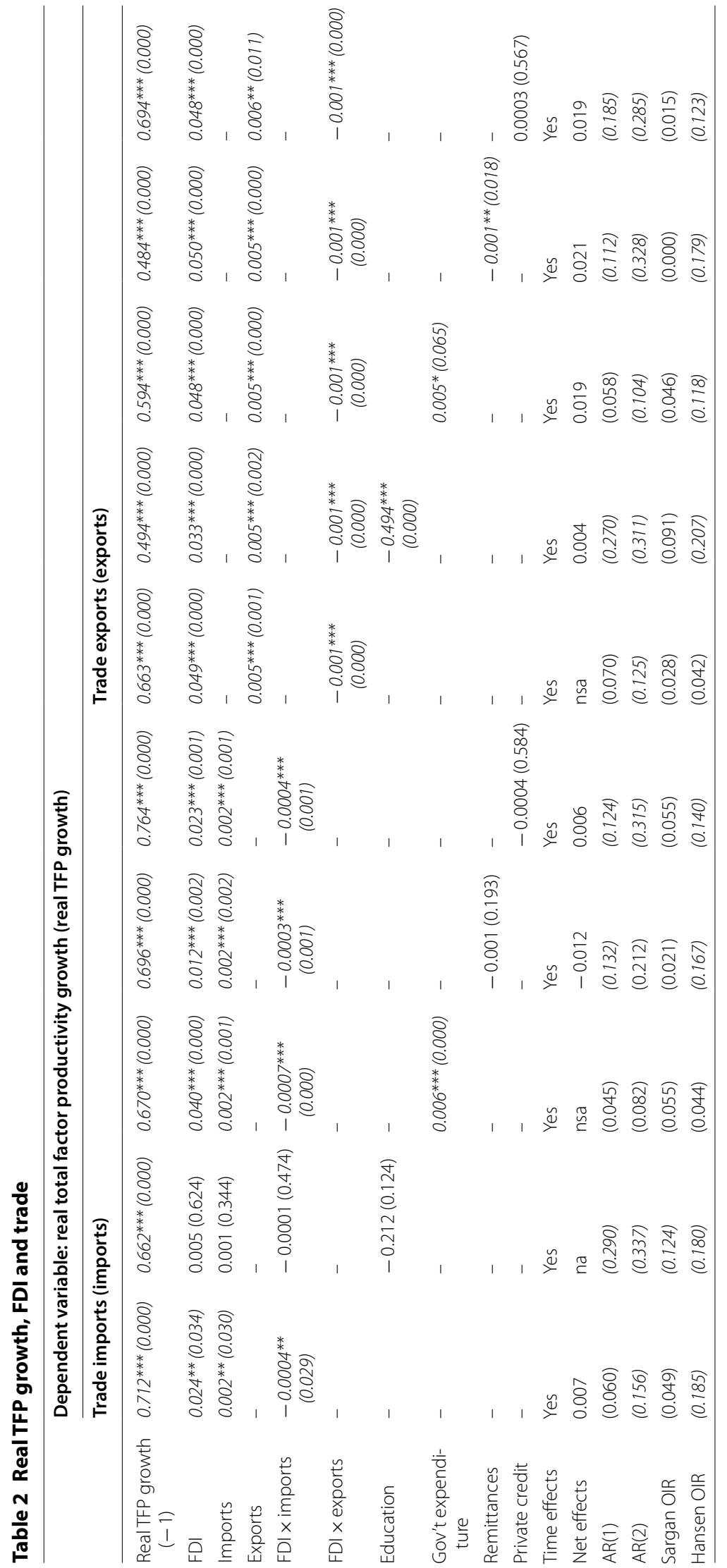




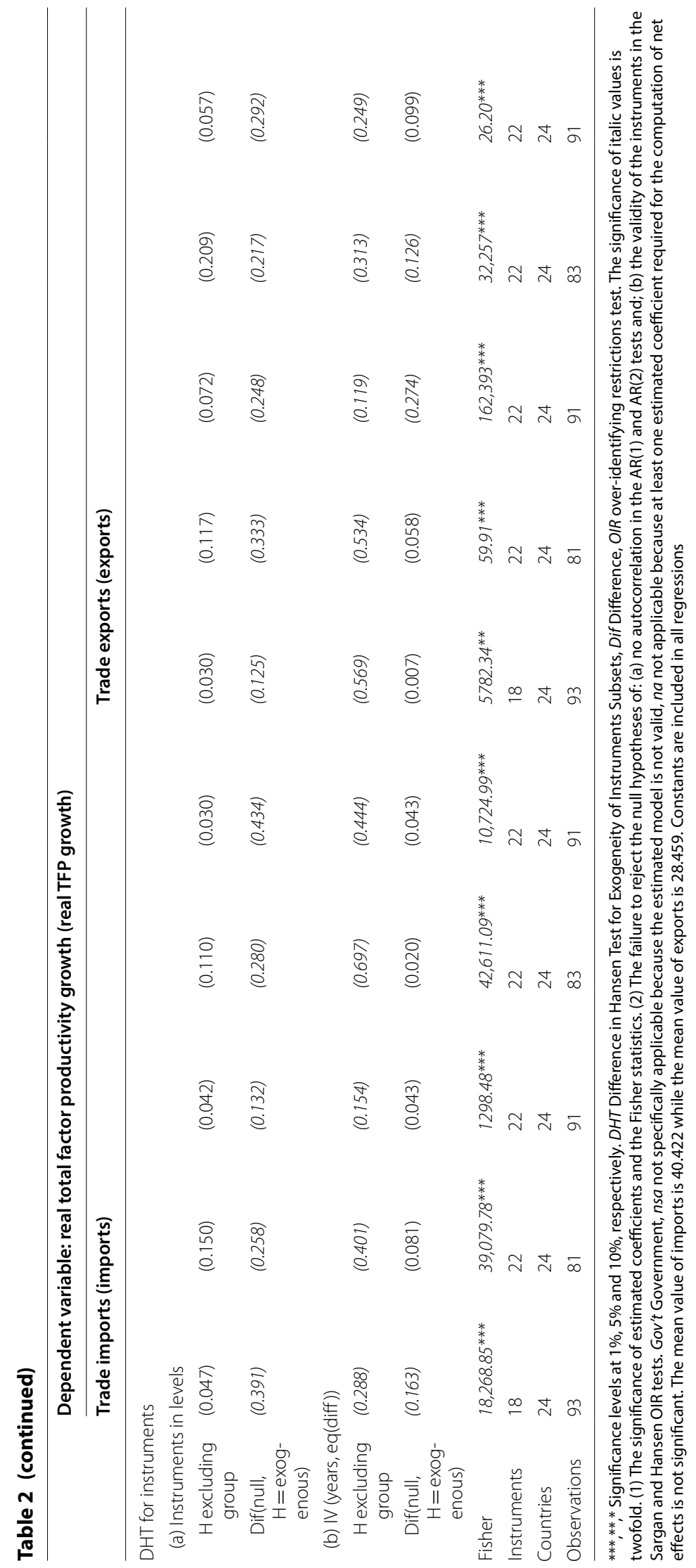




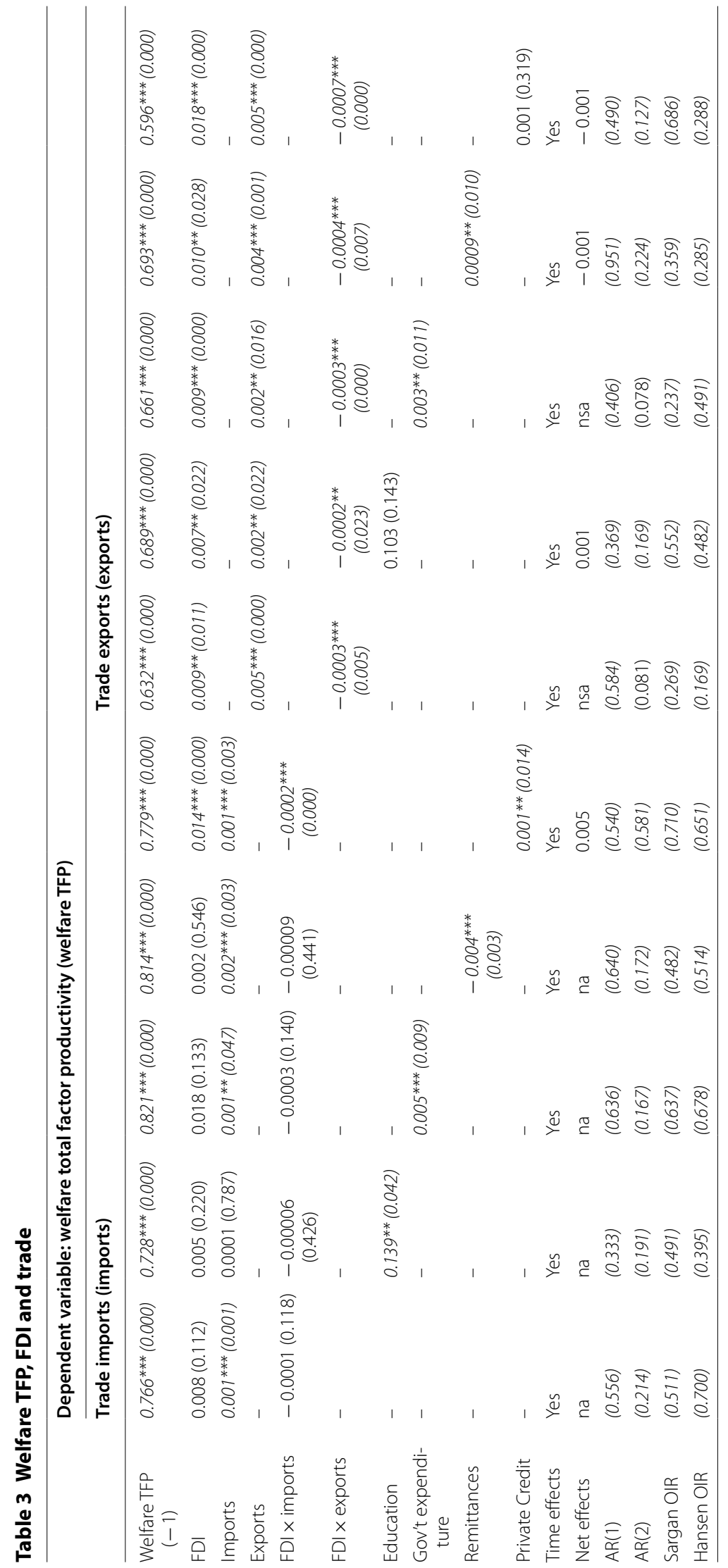




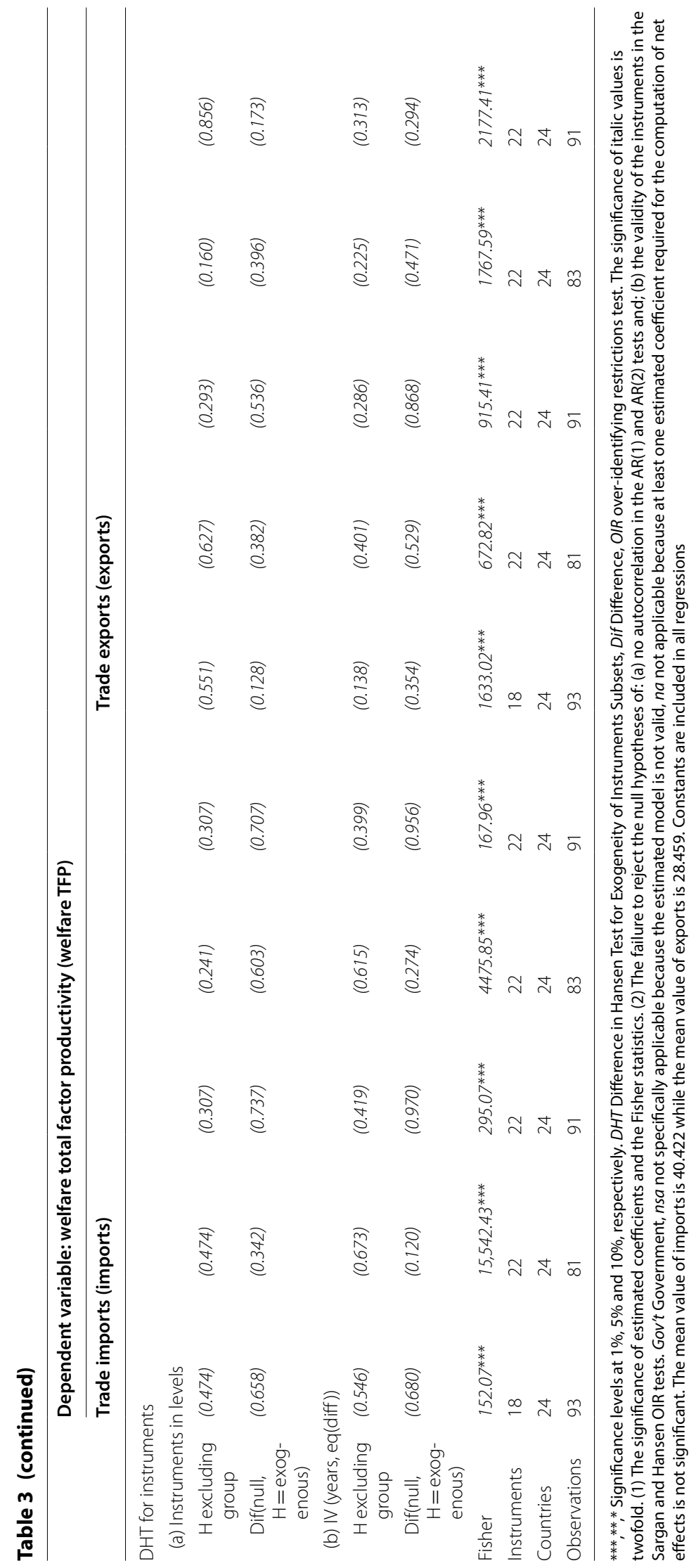




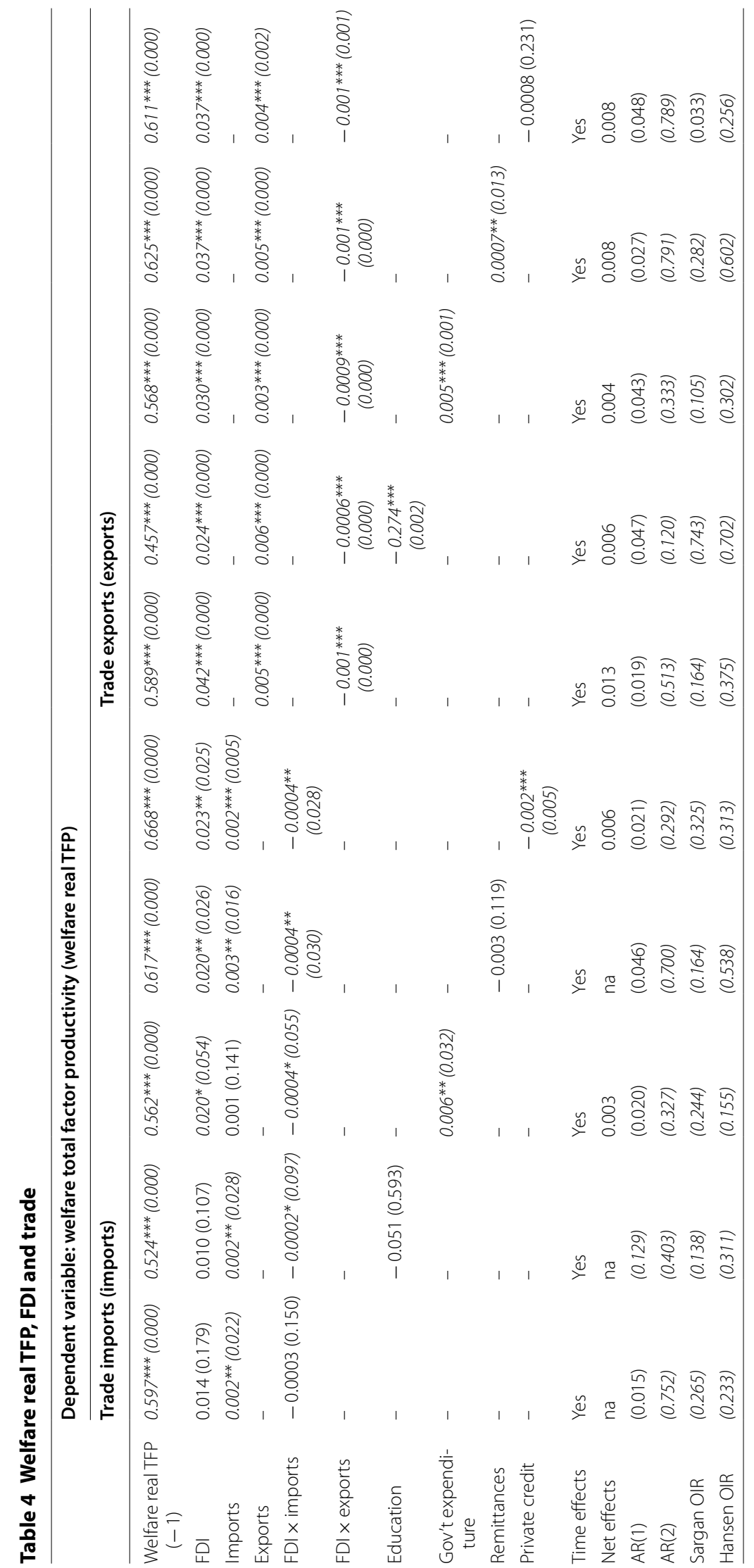




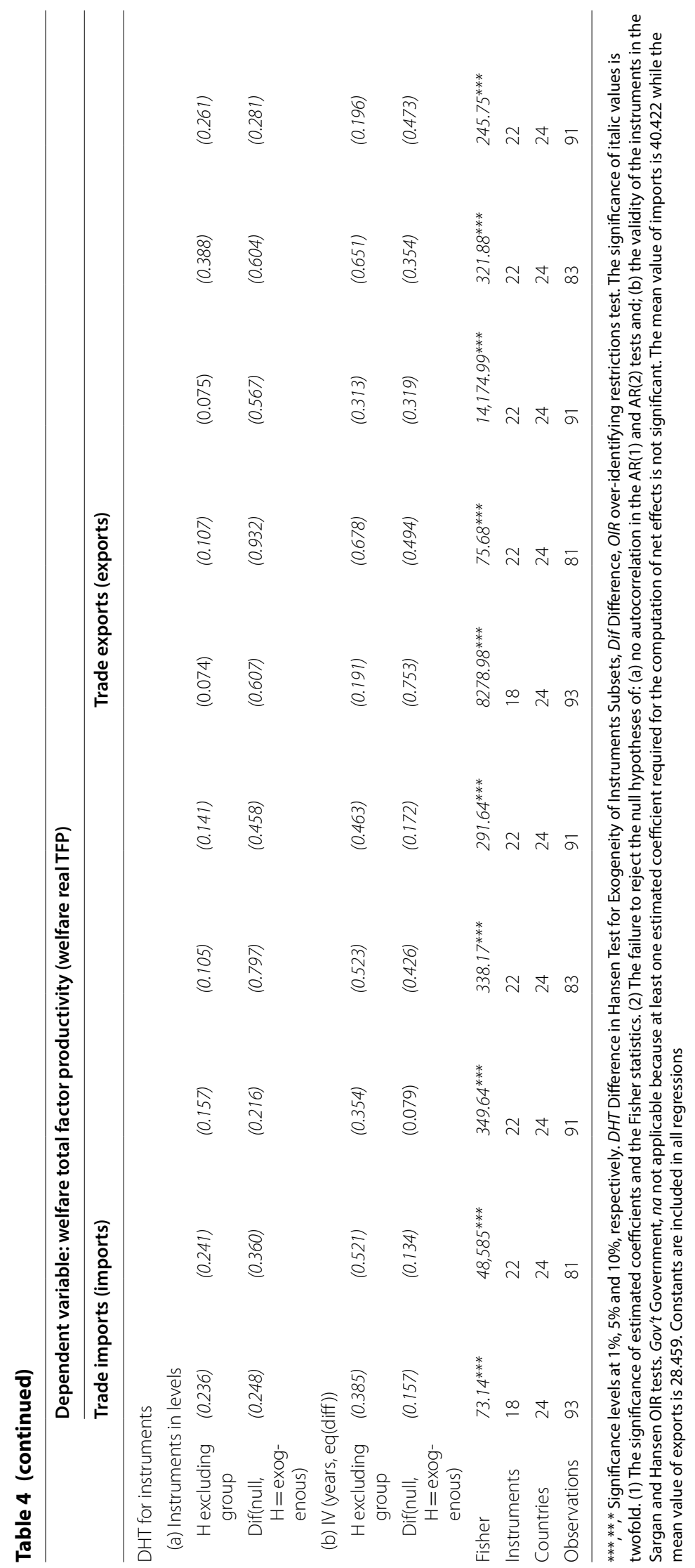


a few exceptions where the null hypotheses are rejected in the: (i) Hansen and (ii) secondorder Arellano and Bond autocorrelation in difference tests. Hence, for these invalid models, net effects are not computed to assess the testable hypothesis motivating this study.

In the light of the above, following contemporary studies founded on interactive regressions (Tchamyou and Asongu 2017; Agoba et al. 2020), the hypothesis motivating this study is assessed by computing net effects from the unconditional effect of FDI and the conditional or interactive effects between FDI and trade dynamics. To put this computation into more perspective, in the second column of Table 1, the net effect on TFP from the relevance of imports in modulating the role of FDI on TFP is 0.003 ([40.4 $22 \times-0.0003]+[0.016])$. In the computation, the average value of imports is 40.422 ; the unconditional impact of FDI on TFP is 0.016 , whereas the conditional effect pertaining to the interaction between exports and FDI is -0.0003 .

The following results are apparent from Tables 1, 2, 3, 4. First, trade imports modulate FDI to overwhelmingly induce positive net effects on TFP, real TFP growth, welfare TFP and real welfare TFP. Second, with exceptions on TFP and welfare TFP where net effects are both positive and negative, trade exports modulate FDI to overwhelmingly induce positive net effects on real TFP growth, welfare real TFP. In summary, the tested hypothesis is valid for the most part. Third, most of the significant control variables reflect the expected signs.

\subsection{Further discussion of results}

While it is relevant to discuss the confirmed simultaneous openness hypothesis in the light of extant literature, it is also worthwhile to note that the Rajan and Zingales (2003) hypothesis pertaining to simultaneous openness has largely been investigated within the context of financial development. Hence, as clarified in the introduction, this study has departed from the extant literature by investigating the attendant hypothesis within the context of productivity. Hence, the discussion of results in the light of prior literature on the simultaneously openness hypothesis would largely compare the findings of this study with those established in the financial development literature. Let us recall that, according to Rajan and Zingales (2003), concurrent opening of trade and capital accounts will lead to greater financial development in a domestic economy and by extension, productivity in a domestic economy as framed in this study. Two strands of the literature are worth comparing with the established findings, notably: a strand that has confirmed the hypothesis and another strand that has not confirmed the hypothesis.

On the strand that has confirmed the hypothesis; the findings of this study are broadly consistent with Sakyi and Egyir (2017) who have confirmed the hypothesis within the context of economic growth in 45 African countries during the period 1990-2014 using the GMM estimation technique. In this same strand, Onanuga (2016) confirms the simultaneous opening of finance and trade accounts for financial development in Nigeria using the GMM estimation strategy while Law (2017) establishes using dynamic heterogeneous panel data (from 68 countries for the period 1980-2001) that, openness in terms of capital and trade are most potent in driving financial development in middle-income nations, compared to high-income and low-income countries where the influence is relatively small.

With respect to the strand of studies that has not confirmed the underlying hypothesis, Ajayi and Aluko (2019) use data from 1990 to 2015 and an instrumental variable estimation approach to establish that simultaneous increases in financial and trade 
openness restrict stock market and banking sector developments in Nigeria. Baltagi et al. (2009) provide only partial support for the hypothesis by finding that opening either trade accounts or capital accounts (i.e. opening one without the other) can still improve financial sector development. Using GMM estimators on data from 1996 to 2013 in 53 developing and developed countries, Abdallah (2016) does not find support to the simultaneous openness hypothesis. Al-Fayoumi and Abuzayed (2014) have also not confirmed the hypothesis in 12 Arab countries from 1985 to 2011 using the GMM, fixed effects and random effects estimation strategies. Hauner et al. (2013) also find little support for the underlying hypothesis using de jure measures of openness and financial development. Karimu and Marbuah (2017) focus on 44 developing economies and use a nonparametric modelling approach to confirm that both openness dimensions positively affect financial development and consequently, provide loose support for the simultaneous openness hypothesis.

It is worth noting that the conclusions on evidences or not of the simultaneous opening hypothesis from the extant literature are based on interactive effects, while the conclusions of this study are based on net effects. It follows that findings of the studies used to compare our findings are characterized by some pitfalls in interactive regressions documented in Brambor et al. (2006) and contemporary literature (Asongu and Odhiambo 2020a, b). Accordingly, in interactive regressions, the overall effect should be based on both the conditional (or interactive effect) and the unconditional effect.

\section{Concluding implications and future research directions}

This study assesses the simultaneous openness hypothesis that trade modulates foreign direct investment (FDI) to induce positive net effects on total factor productivity (TFP) dynamics. Twenty-five countries in Sub-Saharan Africa and data for the period 1980 to 2014 are used. The empirical evidence is based on the Generalized Method of Moments. First, trade imports modulate FDI to overwhelmingly induce positive net effects on TFP, real TFP growth, welfare TFP and real welfare TFP. Second, with exceptions on TFP and welfare TFP where net effects are both positive and negative, trade exports modulate FDI to overwhelmingly induce positive net effects on real TFP growth and welfare real TFP. In summary, the tested hypothesis is valid for the most part.

In the light of the above, the tested hypothesis is overwhelmingly valid because the positive net effects substantially outweigh the negative net effects. Evidence of positive and negative net effects is not also surprising given the conflicting theoretical underpinnings engaged in Sect. 2. The negative net effects can also be elicited from several perspectives. FDI may not engender positive ramifications on TFP if multinational companies operate within sectors that are not competitive or when FDI is implemented within a context whereby it dampens domestic investment and savings. Hence, FDI can also enclave investment, reduce external balances owing to substantial repatriation of profits. It is also important to emphasize that in scenarios where FDI is not tailored to international trade, but for domestic consumption, limited exports can adversely affect the current account balance and by extension foreign reserves. In summary, the fact that the overall effects on the outcome variable are contingent on adopted elements in the conditioning information set is also evidence of the fact that initial macroeconomic conditions are necessary in order to leverage on overall positive effects. Moreover, some initial conditions are 
more favourable for the anticipated positive net effects than others. In what follows, some implications pertaining to the validity of the tested hypothesis are engaged.

Overall, it is worthwhile to emphasize that the findings are relevant to the sampled countries in SSA because a trade-driven FDI-TFP nexus is likely to bring in foreign exchange earnings, improve economic performance and encourage the establishment and/or consolidation of new/competitive productivity capacities. The net effects can be further improved if the established nexuses are tailored in the light of the following.

First, the established findings should be fundamentally articulated along the imperative of fostering export-oriented FDI given that the suggested approach has the advantage of attracting investments that contribute both to the consolidation of foreign exchange and domestic employment opportunities. The approach should also be contingent on comparative competitiveness of the countries, strategic niches of production, targeted locations and the relevance of productivity that is aligned with global value chains.

Second, the positive net effects on welfare-focused TFP dynamics is evidence of the relevance of the findings in the post-2015 development agenda in which, societal welfare is fundamental in driving sustainable development. Hence, FDI policies should also be constructively aligned to the degree by which the targeted productivity can boost socioeconomic and inclusive development objectives of sampled countries. Therefore, the FDI approaches should be tailored to promote, the rights of workers, working conditions and skills upgrading.

Third, in order to boost domestic economic development in other sectors and improve values chains, foreign investors should be encouraged to foster nexuses with local firms and suppliers. Moreover, the linkages should promote knowledge transfer, technology catch-up and skills diffusion between domestic firms and multinational companies. Other worthwhile endeavours that should be prioritized in the connection between multinational companies and local firms include: collaborative training, participation in joint programmes for human capital improvement and encouragement of foreign partners to contribute towards the construction of local capacities.

Fourth, the imperative of fostering and consolidating export-related FDI is contingent on the nation's capacity to build domestic resources. Accordingly, as established by Hassan (2005), countries that have been most successful in driving-up exports have adopted a two-pronged strategy: improvement of domestic capabilities and foreign resources targeting. The approach entails, inter alia: the institution of specialized agencies that promote the targeting of FDI in accordance with industrial strategies and broader development objectives of a nation; upgrading of human resources and system of training workers; building of relevant industrial infrastructure that is of world premier standard; establishment of funds promoting capital investment and support for domestic corporations.

Fifth, in summary, in order to improve overall productivity as well as welfare implications of the underlying productivity, countries also need to be aware of issues that can substantially jeopardize the development prospects of SSA nations. Such issues include a good understanding of tendencies in comparative advantages such that domestic policies are designed to avoid foreign investments that are weapons of dumping and unfair competition. In essence, the degree by which nations can benefit from new avenues brought about by systems of international production is contingent on the their idiosyncratic actions, which entail: the consolidation of institutional 
frameworks, promotion of investment opportunities that are export-oriented and building of networks for skills and technology transfer between multinational companies and local firms.

The findings obviously leave room for future research particularly, within the framework of understanding how the formation of industrial clusters can be consolidated by trade openness in efforts to form three types of FDI-driven clusters. These are: (i) targeted business and investment promotion; (ii) institutions building and (iii) training of human resources.

\section{Acknowledgements}

The authors are indebted to the editor and reviewers for constructive comments.

\section{Authors' contributions}

SAA participated in the writing of the manuscript and data analysis. JN participated in the revision of the manuscript. PNA participated in the revision of the manuscript. All authors read and approved the final manuscript.

\section{Authors' information}

Prof. Simplice Asongu holds a PhD from Oxford Brookes University and is currently the Lead Economist and Director of the African Governance and Development Institute (Yaoundé, Cameroon); the Lead Economist and Director of the European Xtramile Centre of African Studies (Liège, Belgium) and Lead Economist and Directors of Centre de Recherche pour le Développement Economique (Bangui, Central African Republic). He is also a: Senior Research Fellow at the Africa Growth Institute (Cape Town, South Africa); PhD Supervisor at Covenant University (Ota, Nigeria), the University of Ghana (Accra, Ghana); Antioch University (Los Angeles, Santa Barbara, Midwest, New England, Seattle, USA) and Midlands State University (Gweru, Zimbabwe); DBA Supervisor at Management College of Southern Africa (Durban, South Africa) and Research Associate at the Research Network Africa (Gaborone, Botswana), University of South Africa (Pretoria, South Africa), University of Buea (Buea, Cameroon) and Oxford Brookes University (Oxford, UK). He is also Associate Editor in some journals including the Journal of Economic Surveys, the Journal of African Business and the Emerging Markets Finance and Trade.

Prof. Joseph Nnanna currently serves as the chief economist of the Development Bank of Nigeria (DBN) PLC. A seasoned professional with numerous years of experience in the US mortgage, banking, manufacturing, and telecommunication industry before joining academia. Prior to joining DBN, Nnanna was a tenured professor of business and economics at Northwestern Oklahoma State University. His scholarly works have been published in the DBN Journal of Economics and Sustainable Growth, Foreign Trade Review, and International Journal of Business Economics and Management, among others. Nnanna's areas of research are development finance, macroeconomics, and trade, respectively. He is a member of the American Economic Association.

Dr. Paul Nkemngu Acha-Anyi holds a Doctorate degree in Tourism Management from the North-west University in South Africa and serves as senior lecturer in the department of Tourism, Hospitality and Sports Management at Walter Sisulu University in South Africa. He also works as research supervisor and external examiner for a number of Universities including the University of South Africa (UNISA — Graduate School of Business Leadership), the University of Johannesburg (School of Tourism \& Hospitality), Tshwane University of Technology, University of Namibia (UNAM-Business School) among others. Paul has over fifteen (15) years' experience in lecturing and research supervision at tertiary level. He has edited two academic books, namely: Introduction to tourism planning and development: igniting Africa's tourism economy" (2018) and Fundamentals of tourism: an African perspective (2020), published by Van Schaik publishers. He is also the founder and Executive Director of two renowned community development initiatives: Achas University Institute of Tourism and Business Management in Cameroon and Achas Safari Africa Magazine. Paul is passionate about research and initiatives that foster local economic development and advocates a Pan-African approach to tourism development.

\section{Funding}

This is an unfunded paper.

Availability of data and materials

The data for this paper are available upon request.

Ethics approval and consent to participate

This article does not contain any studies with human participants or animals performed by the authors.

\section{Consent for publication}

Not applicable.

Competing interests

The authors declare that they have no competing interests.

\section{Author details}

${ }^{1}$ African Governance and Development Institute, P.O Box 8413, Yaoundé, Cameroon. ${ }^{2}$ The Development Bank of Nigeria The Clan Place, Plot 1386A Tigris Crescent, Maitama, Abuja, Nigeria. ${ }^{3}$ Department of Tourism, Hospitality and Sports Management, College Street Campus, Walter Sisulu University, Buffalo, Eastern Cape Province, South Africa. 


\section{Appendices}

Appendix 1

See Table 5.

Table 5 Definitions and sources of variables

\begin{tabular}{|c|c|c|c|}
\hline Variables & Signs & $\begin{array}{l}\text { Variable definitions } \\
\text { (measurements) }\end{array}$ & Sources \\
\hline TFP1 & TFP & Total factor productivity (TFP) & Penn World Table database \\
\hline TFP2 & RTFP & $\begin{array}{l}\text { Real total factor productivity growth } \\
\text { (RTFPg) }\end{array}$ & Penn World Table database \\
\hline TFP3 & WTFP & $\begin{array}{l}\text { Welfare total factor productivity } \\
\text { (WTFP) }\end{array}$ & Penn World Table database \\
\hline TFP4 & WRTFP & $\begin{array}{l}\text { Welfare real total factor productivity } \\
\text { (WRTFP) }\end{array}$ & Penn World Table database \\
\hline Foreign direct investment & FDI & $\begin{array}{l}\text { Foreign direct investment inflows } \\
\text { (\% of GDP) }\end{array}$ & UNCTAD \\
\hline Commodity imports & Imports & $\begin{array}{l}\text { Import of goods and services (\% } \\
\text { of GDP) }\end{array}$ & WDI \\
\hline Commodity exports & Exports & $\begin{array}{l}\text { Export of goods and services (\% } \\
\text { of GDP) }\end{array}$ & WDI \\
\hline Education & Education & $\begin{array}{l}\text { SEPSGPI: school enrollment, primary } \\
\text { and secondary (gross), gender } \\
\text { parity index (GPI) }\end{array}$ & WDI \\
\hline Government expenditure & Gov't expenditure & $\begin{array}{l}\text { Governments final consumption } \\
\text { expenditure (\% of GDP) }\end{array}$ & WDI \\
\hline Remittances & Remittances & $\begin{array}{l}\text { Personal remittances, received (\% } \\
\text { of GDP) }\end{array}$ & WDI \\
\hline Credit access & Private credit & $\begin{array}{l}\text { Domestic credit to private sector (\% } \\
\text { of GDP) }\end{array}$ & FDSD \\
\hline
\end{tabular}

WDI World Development Indicators, GDP Gross Domestic Product, UNCTAD United Nations Conference on Trade and Development, FDSD Financial Development and Structure Database 


\section{Appendix 2}

See Table 6.

Table 6 Summary statistics

\begin{tabular}{lrrrrl}
\hline & Mean & SD & Minimum & Maximum & Observations \\
\hline Total factor productivity & 0.539 & 0.310 & 0.121 & 1.884 & 125 \\
Real total factor productivity growth & 0.539 & 0.276 & 0.123 & 1.381 & 125 \\
Welfare total factor productivity & 0.984 & 0.189 & 0.605 & 1.664 & 125 \\
Welfare real total factor productivity & 0.927 & 0.190 & 0.456 & 1.785 & 125 \\
Foreign direct investment & 1.903 & 2.795 & -3.440 & 22.118 & 124 \\
Imports & 40.422 & 26.980 & 6.664 & 163.198 & 116 \\
Exports & 28.459 & 16.635 & 3.199 & 66.722 & 116 \\
Education & 0.854 & 0.177 & 0.465 & 1.341 & 107 \\
Government expenditure & 16.066 & 5.358 & 6.085 & 36.155 & 122 \\
Remittances & 4.768 & 12.917 & 0.003 & 89.354 & 107 \\
Credit access & 21.009 & 22.256 & 2.238 & 144.397 & 121 \\
\hline
\end{tabular}

SD standard deviation

\section{Appendix 3}

See Table 7. 


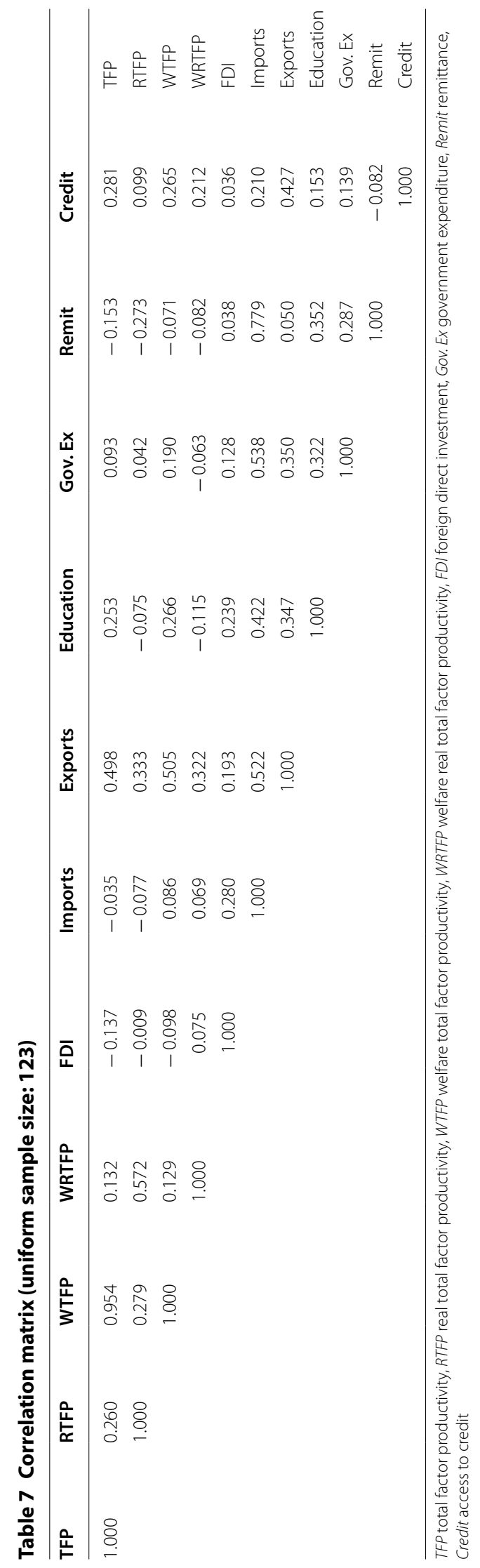


Received: 30 October 2019 Revised: 2 January 2020 Accepted: 18 January 2020

Published online: 01 February 2020

\section{References}

Abdallah ZT (2016) An evaluation of simultaneous openness hypothesis in the context of stock market development: evidence from a panel of fifty three countries based a GMM Study. Mod Econ 7(2):153-163

Abramovitz M (1986) Catching up, forging ahead, and falling behind. J Econ Hist 46(02):385-406

Agoba AM, Abor J, Osei KA, Sa-Aadu J (2020) Do independent central banks exhibit varied behaviour in election and non-election years: the case of fiscal policy in Africa. J Afr Bus 21(1):105-125

Ahouakan EWV, Diene M (2017) Does school quality matter? Primary schools characteristics and child labour intensity in Senegal. J Afr Dev 19(1):113-131

Ajayi MA, Aluko OA (2019) Testing the validity of the simultaneous openness hypothesis in Nigeria (1990-2015). Afr Dev Rev 31(1):58-70

Al-Fayoumi N, Abuzayed B (2014) Does openness enhance financial sector development? The experience of the Arab world. EuroMed J Bus 9(3):318-332

Amavilah A, Asongu SA, Andrés AR (2017) Effects of globalization on peace and stability: Implications for governance and the knowledge economy of African countries. Technol Forecast Soc Change 122(1):91-103

Arellano M, Bover O (1995) Another look at the instrumental variable estimation of error components models. J Econometrics 68(1):29-52

Asiedu E (2014) Does foreign aid in education promote economic growth? Evidence from Sub-Saharan Africa. J Afr Dev 16(1):37-59

Asongu SA (2013) Globalization and Africa: implications for human development. Int J Dev Issues 12(3):213-238

Asongu SA (2014a) Financial development dynamic thresholds of financial globalisation: evidence from Africa. J Econ Stud 41(2):166-195

Asongu SA (2014b) Globalisation (fighting) corruption and development. How are these phenomena linearly and nonlinearly related in wealth effects? J Econ Stud 41(3):346-369

Asongu SA (2015) Finance and growth: new evidence from Meta-analysis. Manag Finance 41(6):615-639

Asongu SA (2017) Knowledge economy gaps, policy syndromes, and catch-up strategies: fresh South Korean Lessons to Africa. J Knowl Econ 8(1):211-253

Asongu SA (2020) Financial access and productivity dynamics in Sub-Saharan Africa. Int J Public Admin. https://doi. org/10.1080/01900692.2019.1664570

Asongu SA, De Moor L (2017) Financial globalisation dynamic thresholds for financial development: evidence from Africa. Eur J Dev Res 29(1):192-212

Asongu SA, Nwachukwu JC (2017a) Globalization and inclusive human development in Africa. Man Econ 4(1):1-24

Asongu SA, Nwachukwu JC (2017b) The comparative inclusive human development of globalisation in Africa. Soc Indic Res 134(3):1027-1050

Asongu SA, Nwachukwu JC (2017c) Quality of growth empirics: comparative gaps, benchmarking and policy syndromes. J Policy Model 39(5):861-882

Asongu SA, Nwachukwu JC (2017d) Foreign aid and inclusive development: updated evidence from Africa, 2005-2012. Soc Sci Quart 98(1):282-298

Asongu SA, Odhiambo NM (2020a) Insurance policy thresholds for economic growth in Africa. Eur J Dev. https://doi. org/10.1057/s41287-019-00234-2

Asongu SA, Odhiambo NM (2020b) Foreign direct investment, information technology and economic growth dynamics in Sub-Saharan Africa. Telecommun Policy. https://doi.org/10.1016/j.telpol.2019.101838

Asongu SA, le Roux S, Biekpe N (2017) Environmental degradation, ICT and inclusive development in Sub-Saharan Africa. Energy Policy 111 (December):353-361

Asongu SA, Biekpe N, Tchamyou VS (2019) "Remittances, ICT and doing business in Sub-Saharan Africa. J Econ Stud 46(1):35-54

Asongu SA, Nnanna J, Acha-Anyi PN (2020) The openness hypothesis in the context of economic development in SubSaharan Africa: the moderating role of Trade Dynamics on FDI. In: African governance and development institute working paper

Baliamoune M (2009) Openness, growth and convergence in Africa: evidence from 1980-1999 data. J Afr Dev 11(1):109-126

Baliamoune-Lutz M (2011) Growth by destination (where you export matters): trade with China and growth in African countries. Afr Dev Rev 23(2):202-218

Baltagi BH, Demetriades PO, Law SH (2009) Financial development and openness: evidence from panel data. J Dev Econ 89(2):285-296

Barro JR (2003) Determinants of economic growth in a panel of countries. Ann Econ Finance 4(2):231-274

Beck T, Demirgüç-Kunt A, Levine R (2003) Law and finance: why does legal origin matter?". J Comp Econ 31(4):653-675

Becker GS, Laeser EL, Murphy KM (1999) Population and economic growth. Am Econ Rev 89(2):145-149

Boamah NA (2017) The relevance of global sector influence in African sector portfolios. Afr J Econ Manag Stud 8(2):205-220

Boateng A, Asongu SA, Akamavi R, Tchamyou VS (2018) Information asymmetry and market power in the african banking industry. J Multinatl Finance Manag 44(March):69-83

Brambor T, Clark WM, Golder M (2006) Understanding interaction models: improving empirical analyses. Polit Anal 14(1):63-82

Cheruiyot KJ (2017) Determinants of technical efficiency in kenyan manufacturing sector. Afr Dev Rev 29(1):44-55 
Cisse F (2017) Do firms learn by exporting or learn to export? Evidence from senegalese manufacturing firms. J Afr Dev 19(1):133-160

Devarajan S, Easterly WR, Pack H (2003) Low investment is not the constraint on African development. Econ Dev Cult Change 51(3):547-571

Dunne JP, Nicholas Masiyandima N (2017) Bilateral FDI from South Africa and income convergence in SADC. Afr Dev Rev 29(3):403-415

Durlauf S, Johnson P, Temple J (2005) Growth econometrics. In: Aghion P, Durlauf S (eds) Handbook of Economic Growth. Elsevier, North Holland

Easterly W, Levine R (2001) It's not factor accumulation: stylized facts and growth models. World Bank Econ Rev 15(2): $177-220$

Efobi R, Asongu S, Okafor C, Tchamyou S, Tanankem B (2019) Remittances, finance and industrialisation in Africa. J Multinatl Finance Manag 49(March):54-66

Elu JU, Price GN (2010) Does china transfer productivity enhancing technology to Sub-Saharan Africa? Evidence from manufacturing firms. Afr Dev Rev 22(S1):587-598

Elu JU, Price GN (2017) Science labor supply in Sub-Saharan Africa: is there a gender disparity in preferences? Afr Dev Rev 29(3):367-375

Fanta AB, Makina D (2017) Equity, bonds, institutional debt and economic growth: evidence from South Africa. S Afr J Econ 85(1):86-97

Fedderke JW, Mengisteab DK (2017) Estimating South Africa's output gap and potential growth rate. S Afr J Econ 85(2):161-177

Gammoudi M, Cherif M, Asongu SA (2016) FDI and growth in the MENA countries: are the GCC countries different? African Governance and Development Institute No. WP/16/015, Yaoundé

Grennes T (2003) Creative destruction and globalization. Cato J 22(3):543-558

Hassan MK (2005) FDI, information technology and economic growth in the Mena region. 10th ERF paper. http://www. mafhoum.com/press6/171T42.pdf. Accessed 21 Feb 2019

Hauner D, Prati A, Bircan C (2013) The interest group theory of financial development: evidence from regulation. J Bank Finance 37(2013):895-906

Heady DD, Hodge A (2009) The effect of population growth on economic growth: a meta-regression analysis of the macroeconomic literature. Popul Dev Rev 35(2):221-248

Holmes TJ, Schmitz JA (1995) Resistance to new technology and trade between areas. Reserv Bank Minneapolis Quarterly Rev 19(1):1-14

Hussien A, Ahmed S, Yousaf M (2012) Does Trade Policy Explain Total Factor Productivity Differences Across Countries? MPRA Paper No. 86594, Munich. https://mpra.ub.uni-muenchen.de/86594/9/MPRA_paper_86594.pdf. Accessed 03 Mar 2019

Javorcik BS (2004) Does foreign direct investment increase the productivity of domestic firms? In search of spillovers through backward linkages. Am Econ Rev 94(3):605-627

Jensen NM (2008) Nation-States and the multinational corporation: a political economy of foreign direct investment. Princeton University Press, Princeton

Karimu A, Marbuah G (2017) Re-examining the financial development-openness nexus: nonparametric evidence for developing countries. J Appl Econ 20(2):373-394

Klenow PJ, Rodriguez-Clare A (1997) The neoclassical revival in growth economics: has it gone too far? NBER Macroeconomics Annual. pp 73-114

Kreuser CF, Newman C (2018) Total factor productivity in South African manufacturing Firms. S Afr J Econ 86(S1):40-78

Law SH (2017) Openness and financial development: panel data evidence from various stages of economic development. J Emerg Market Finance 6(2):145-165

Love I, Zicchino L (2006) Financial development and dynamic investment behaviour: evidence from panel VAR. Quart Rev Econ Finance 46(2):190-210

Maryam K, Jehan Z (2018) Total factor productivity convergence in developing countries: role of technology diffusion. S Afr J Econ 86(2):247-262

Melitz MJ (2003) The impact of trade on intra-industry reallocations and aggregate industry productivity. Econometrica $71(6): 1695-1725$

Meniago C, Asongu SA (2018) Revisiting the finance-inequality nexus in a panel of African countries. Res Int Bus Finance 46(December):399-419

Meniago C, Asongu SA (2019) Harnessing FDI spillovers on TFP and economic growth in Sub-Saharan Africa: the relevance of value chains across economic sectors. In: African governance and development institute working paper, Yaoundé

Nelson RR, Howard Pack H (1999) The asian growth miracle and modern growth theory. Econ J 109(457):416-436

Nyasha S, Odhiambo NM (2015a) Do banks and stock market spur economic growth? Kenya's experience. Int I Sustain Econ 7(1):54-65

Nyasha S, Odhiambo NM (2015b) The impact of banks and stock market development on economic growth in South Africa: an ARDL-bounds testing approach. Contemp Econ 9(1):93-108

Onanuga OT (2016) Do financial and trade openness lead to financial sector development in Nigeria? Zagreb Int Rev Econ Bus 19(2):57-68

Osabuohien ES, Efobi UR (2013) Africa's money in Africa. S Afr J Econ 81(2):292-306

Petrakis PE, Stamatakis D (2002) Growth and educational levels: a comparative analysis. Econ Educ Rev 21 (2):513-521

Petras J, Veltmeyer H (2001) Globalization Unmasked: Imperialism in the 21st Century. Zed Books, London

Rajan RG, Zingales L (2003) The great reversal: the politics of financial development in the twentieth century. J Finance Econ 69(2003):5-50

Romer PM (1986) Increasing returns and Long-run growth. J Polit Econ 94(5):1002-1037

Romer PM (1993) Idea gaps and object gaps in economic development. J monetary Econ 32(3):543-573

Roodman D (2009) How to do Xtabond2: an introduction to difference and system GMM in Stata. Stata J 9(1):86-136 
Sahoo P, Dash RK, Nataraj G (2010) Infrastructure development and economic growth in China. In: IDE discussion paper No. 261, Chiba

Sakyi D, Egyir J (2017) Effects of trade and FDI on economic growth in Africa: an empirical investigation. Trans Corp Rev 9(2):66-87

Scholte JA (2000) Globalisation: a critical introduction. St. Martin's Press Inc, New York

Sirgy MJ, Lee DJ, Miller C, Littlefield JE (2004) The impact of globalization on a country's quality of life: toward an integrated model. Soc Indictors Res 68(3):251-298

Smart B (2003) Economy, culture and society: a sociological critique of neo-liberalism. Open University Press, Buckingham

Ssozi J, Asongu SA (2016a) The comparative economics of catch-up in output per worker, total factor productivity and technological gain in Sub-Saharan Africa. Afr Dev Rev 28(2):215-228

Ssozi J, Asongu SA (2016b) The effects of remittances on output per worker in Sub-Saharan Africa: a production function approach. S Afr J Econ 84(3):400-421

Taylor M, Thrift N (2013) The geography of multinationals: studies in the spatial development and economic consequences of multinational corporations. Routledge, Abingdon

Tchamyou VS (2017) The role of knowledge economy in african business. J Knowl Econ 8(4):1189-1228

Tchamyou VS (2019) The role of information sharing in modulating the effect of financial access on inequality. J Afr Bus 20(3):317-338

Tchamyou VS (2020) Education, lifelong learning, inequality and financial access: evidence from african countries. Contemp Soc Sci. https://doi.org/10.1080/21582041.2018.1433314

Tchamyou VS, Asongu SA (2017) Information sharing and financial sector development in africa. J Afr Bus 18(7):24-49

Tchamyou VS, Asongu SA, Nwachukwu JC (2018) Effects of asymmetric information on market timing in the mutual fund industry. Int J Manag Finance 14(5):542-557

Tchamyou VS, Erreygers G, Cassimon D (2019) Inequality, ICT and financial access in Africa. Technol Forecast Soc Chang 139(February):169-184

Temple J (1999) The new growth evidence. J Econ Lit 37(1):112-156

Toone JE (2013) Mirage in the Gulf?: examining the upsurge in FDI in the GCC and its legal and economic implications for the MENA region. (SSRN Scholarly Paper No. ID 2150603). Social Science Research Network, Rochester, NY

Tsai M (2006) Does globalisation affect human well-being?. Department of Sociology, National Taipei University, Taipei

Young A (1995) The tyranny of numbers: confronting the statistical realities of the east asian growth experience. Quart J Econ 110(3):641-680

\section{Publisher's Note}

Springer Nature remains neutral with regard to jurisdictional claims in published maps and institutional affiliations.

\section{Submit your manuscript to a SpringerOpen ${ }^{\circ}$ journal and benefit from:}

- Convenient online submission

- Rigorous peer review

- Open access: articles freely available online

- High visibility within the field

- Retaining the copyright to your article

Submit your next manuscript at $\boldsymbol{\nabla}$ springeropen.com 